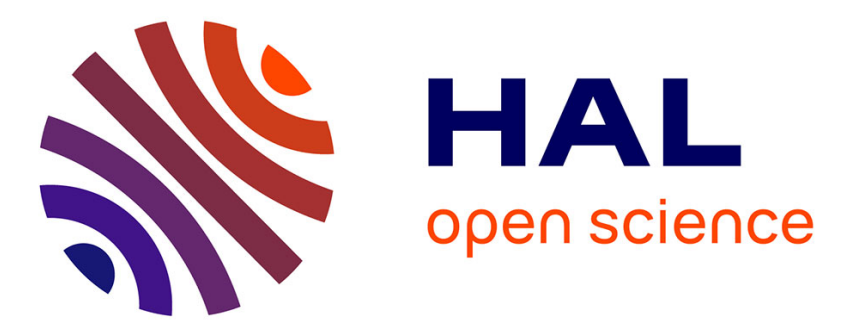

\title{
Distribution of organic contamination of sediments from Ichkeul Lake and Bizerte Lagoon, Tunisia
}

\author{
Fida Ben Salem, O. Ben Said, E. Mahmoudi, Robert Duran, Mathilde
}

Monperrus

\section{- To cite this version:}

Fida Ben Salem, O. Ben Said, E. Mahmoudi, Robert Duran, Mathilde Monperrus. Distribution of organic contamination of sediments from Ichkeul Lake and Bizerte Lagoon, Tunisia. Marine Pollution Bulletin, 2017, 123 (162), pp.329-338. 10.1016/j.marpolbul.2017.09.024 . hal-01617276

\section{HAL Id: hal-01617276 \\ https://hal.science/hal-01617276}

Submitted on 27 Aug 2020

HAL is a multi-disciplinary open access archive for the deposit and dissemination of scientific research documents, whether they are published or not. The documents may come from teaching and research institutions in France or abroad, or from public or private research centers.
L'archive ouverte pluridisciplinaire HAL, est destinée au dépôt et à la diffusion de documents scientifiques de niveau recherche, publiés ou non, émanant des établissements d'enseignement et de recherche français ou étrangers, des laboratoires publics ou privés. 


\title{
Distribution of organic contamination of sediments from Ichkeul Lake and Bizerte Lagoon, Tunisia
}

\author{
Fida Ben Salem $^{\mathrm{a}, \mathrm{b}, \mathrm{c}, \mathrm{d}, *}$, Olfa Ben Said ${ }^{\mathrm{a}, \mathrm{b}, \mathrm{d}}$, Ezzeddine Mahmoudi ${ }^{\mathrm{a}}$, Robert Duran ${ }^{\mathrm{b}, \mathrm{d}}$, \\ Mathilde Monperrus ${ }^{c, d}$ \\ ${ }^{\text {a }}$ Laboratory of Environment Biomonitoring, Faculty of Sciences of Bizerte, University of Carthage, 7021 Zarzouna, Tunisia \\ b Equipe Environnement et Microbiologie, MELODY Group, UMR CNRS IPREM 5254, IBEAS, Université de Pau et des Pays de l'Adour, France \\ ${ }^{\mathrm{c}}$ Laboratoire de Chimie Analytique Bio-Inorganique et Environnement, IPREM UMR 5254 CNRS, Université de Pau et des Pays de l'Adour, France \\ ${ }^{\mathrm{d}}$ Fédération de recherche MIRA, Université de Pau et des Pays de l'Adour, France
}

\begin{abstract}
Analyses of organochlorine pesticides (OCPs), polycyclic aromatic hydrocarbons (PAHs), polychlorinated bi-phenyls (PCBs), and butyl tins (BuSn) were conducted on sediments from Ichkeul Lake-Bizerte Lagoon watershed (Tunisia). A total of 59 compounds (16 PAHs, 12 PCBs, 22 OCPs and 9 BuSn) were measured in 40 surface sediment samples collected during two campaigns. High concentrations of total PAHs were identified in the lagoon ranging from 122 to $19600 \mathrm{ng} \cdot \mathrm{g}^{-1}$. Several OCPs, including endrin, dieldrin, and lindane (Hexachlorocyclohexane or $\mathrm{HCH}$ or BHC) were found in high concentrations in Ichkeul Lake, ranging from 28 to 2012 ng $\mathrm{g}^{-1}$. PAHs and OCPs varied seasonally, in response to the complex hydrology of the watershed. The concentrations of total PCBs ranged between 0.04 and 10.653 ng $g^{-1}$ and suggests low total PCBs sediment contamination, when compared to most international criteria. Total BuSn concentrations range between 67 and 526 ng.g ${ }^{-1}$, which are relatively low when compared to most international criteria and ecological risk assess-ments. This is the first study of organic contamination in Ichkeul Lake (RAMSAR and UNESCO World Heritage site).
\end{abstract}

Polycyclic aromatic hydrocarbons (PAHs), organochlorine pesticides (OCPs), polychlorinated biphenyls (PCBs) are classes of persistent organic pollutants (POPs). These compounds are ubiquitous environmental contaminants of great concern in coastal marine sediments these contaminants enter into the environment from numerous sources, including river run-off, atmospheric precipitation, industry, households and all types of transportation (Wen et al., 1994; Chang et al., 2006). POPs have been detected in various environmental matrices and biota of aquatic ecosystems which receive these pollutants from agricultural and industrial activities (Kukucka et al., 2015; Sharma et al., 2014). Several studies have shed light on the presence of industrial pollutants or priority substances (Wenzel et al., 2003; Deycard et al., 2014) in different environmental matrices (Shu et al., 2000; Vane et al., 2007; Ben Said et al., 2010; Opel et al., 2011). Sediments are thought to be the final compartment in which POPs accumulate. The rapid sorption of
POPs to sediment particles and their long persistence in aquatic sediments make them a practical media to assess contamination of an aquatic ecosystem. Although environmental concentrations are highest near the sources, the presence of contaminants in places distant from primary sources indicates that POPs are persistent in the environment and can be transported at long distances (Pozo et al., 2014). Pollutants from different origins that accumulate in sediments suggest that this matrix is the principal reservoir of environmental contaminants (Birch and Davey, 1995).Many of these compounds are toxic to aquatic life and potentially harmful to humans (Tolosa et al., 2005; Sharma et al., 2014). Coastal lagoons and lakes are generally ecosystems stressed by the impact of large cities, industrial activities and intensive agriculture. Rivers and estuaries can serve as important sources of metal and organic contaminants to coastal marine environments (Pozo et al., 2014; Yang et al., 2014). Bottom sediments are complicated by interfering

\footnotetext{
* Corresponding author at: Equipe Environnement et Microbiologie, UMR CNRS IPREM 5254, IBEAS, Université de Pau et des Pays de l'Adour, France.

E-mail address: fida.bensalem@univ-pau.fr (F. Ben Salem).
} 


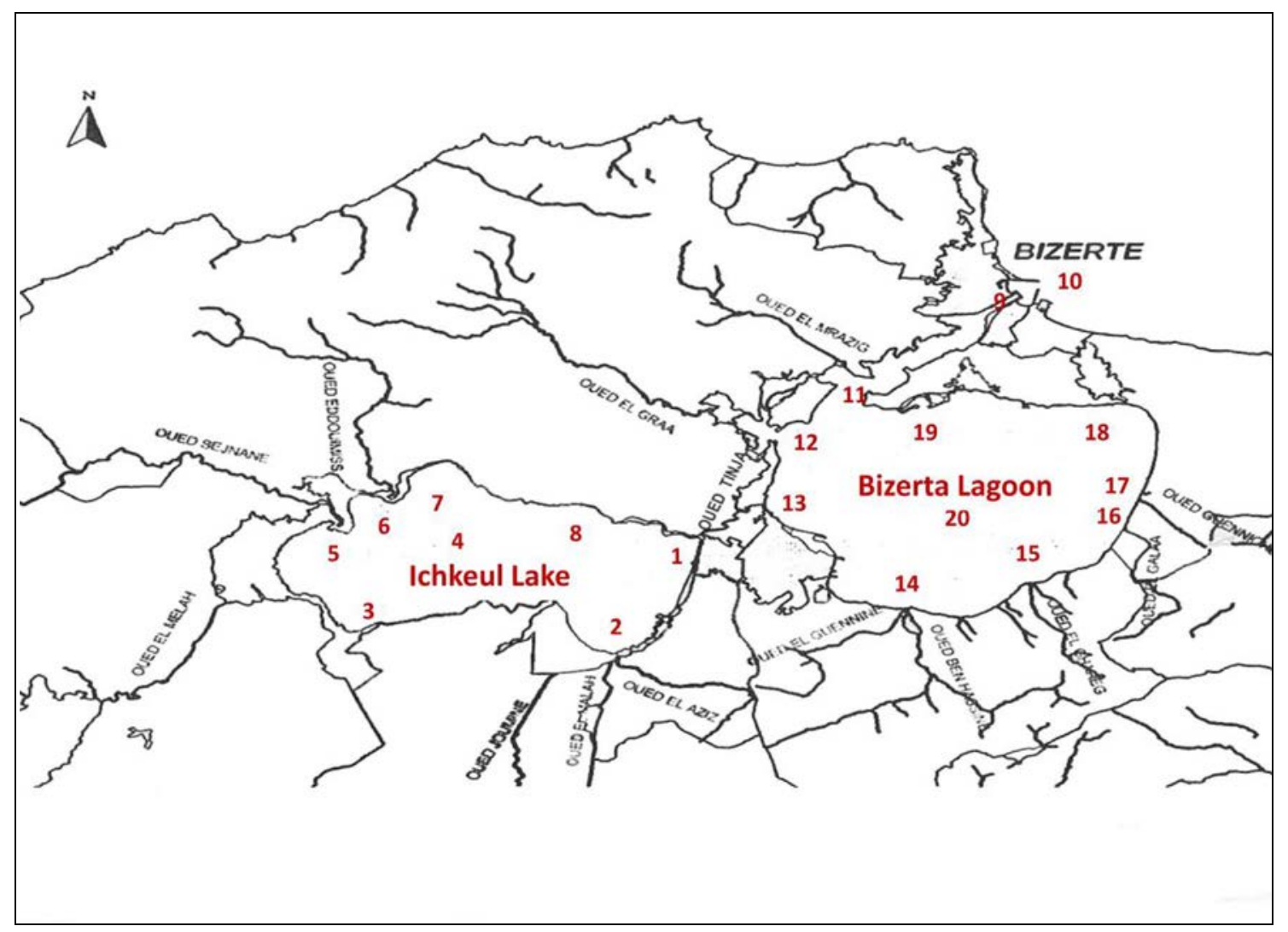

Fig. 1. Map of the Ichkeul Lake-Bizerte Lagoon complex indicating the location of the sampling sites (numbers).

factors (such as binding of organic pollutants) that require complex separation chemistry to produce accurate measurements. In Tunisia, during the past decades researchers have taken the determination of PAHs (Ben Said et al., 2010; Mzoughi et al., 2002; Trabelsi and Driss, 2005) and organotin (Mzoughi et al., 2005) in the sediment of Bizerte Lagoon, but only one study was performed for the determination of PCB contamination in surface sediments at Monastir Bay (Tunisia) (Nouira et al., 2013). Even throughout Tunisia, there is no study reported for the determination of pesticides in sediments but pesticides were investigated in other biological matrices such as human milk, from Bizerte and various Tunisia places (Ben Hassine et al., 2012; Ennaceur et al., 2008), in mullet and sea bass (Ben Ameur et al., 2013). Pollutants from agricultural activities may impact the health of aquatic organisms and subsequently local and migratory birds. Even though Ichkeul Lake is an important migratory area for thousands of birds annually (Stevenson and Battarbee, 1991), it has never been evaluated for POPs contamination.

The current study aimed to investigate the occurrence and distribution patterns of OCPs, PAHs, PCBs and BuSn compounds in sediment of the Ichkeul Lake-Bizerte Lagoon complex (Tunisia). The QuEChERS method validated by Yang et al. (2010) for the analysis of pesticides in soil was adapted for the analysis of OCPs, PAHs and PCBs in sediment samples and was applied with Gas chromatography-mass spectrometry (GC-MS) for the determination of these pollutants. Sediment composition and contaminant profiles from different stations of each ecosystem and the entire complex were compared in order to evaluate the organic contamination and the potential sources.
Organic solvents (hexane, acetone, acetonitrile, and dichloromethane) were of analytical grade and were supplied by Sigma Aldrich. Buffer salt mixture was obtained from Agilent. Deionized water used in the experiment was obtained from a Milli-Q water Ultrapure Water Purification Systems (France).

PCB standard solutions, either as compound mix, containing PCB$18,28,31,70,52,101,138,118,153,149,180,194$ and singles compounds solutions of PCB 209 and PCB 30 were purchased from Sigma Aldrich. The 16 priority PAHs (Naphtalène, Acénaphtène, Acénaphtylène, Fluorène, Phénanthrène, Anthracène, Fluoranthène, Pyrène, Benzo $[a]$ anthracène, Chrysène, Benzo $[b]$ fluoranthène, Benzo $[k]$ fluoranthène, Benzo $[a]$ pyrène, Indéno[1,2,3-cd]pyrène, Benzo[ghi] pérylène, Dibenzo[a,h]anthracène), known as the 16 priority polycyclic aromatic hydrocarbons of US EPA list, as well as two deuterated internal standards phenanthrene-D10 and perylene-D12 were supplied as pure reference materials (purity: 99.5\%) also from Sigma Aldrich. OCPs standard solutions of HCB, aldrin, dieldrin, heptachlor, heptachlor epoxide isomer $B$, endrin, endrinaldehyde, $\alpha$ and $\beta$ endosulfan, endosulfan sulfate, 4,4'-DDE, 4,4'-DDD, 4,4'-DDT, $\alpha$ and $\beta$ chlordane, $\alpha$ and $\beta$ nonachlor and an internal standards atrazine-D5 were purchased from Sigma Aldrich. Standard solutions were prepared in acetonitrile. Tributyltin (TBT) chloride (96\%), dibutyltin (DBT) dichloride (97\%), monobutyltin (MBT) trichloride (95\%) were obtained from SigmaAldrich, whereas trimethyltin (TMeT) chloride (98\%), dimetyltin (DMeT) dichloride (95\%), monometyltin (MMeT) trichloride $(98+\%)$ were obtained from Strem Chemicals (Newburyport, MA, USA). The isotopically enriched butyltin species used were purchased from ISC 
Table 1

Physicochemical parameters of water from the complex Ichkeul Lake-Bizerte Lagoon.

\begin{tabular}{|c|c|c|c|c|c|c|c|c|c|c|c|c|}
\hline ST/HAPs & $\mathrm{T}^{\circ} \mathrm{C}$ & $\mathrm{pH}$ & $\begin{array}{l}\text { Salinity } \\
\text { (PSU) }\end{array}$ & $\begin{array}{l}\text { Conductivity } \\
\left(\mathrm{ms} \mathrm{cm}^{-1}\right)\end{array}$ & $\begin{array}{l}\text { Dissolved } \\
\text { oxygen } \\
\left(\mathrm{mg} \mathrm{l}^{-1}\right)\end{array}$ & $\begin{array}{l}\text { Nitrite } \\
(\mu \mathrm{M})\end{array}$ & $\begin{array}{l}\text { Nitrate } \\
(\mu \mathrm{M})\end{array}$ & $\begin{array}{l}\text { Phosphate } \\
(\mu \mathrm{M})\end{array}$ & $\begin{array}{l}\text { Ammonium } \\
(\mu \mathrm{M})\end{array}$ & $\begin{array}{l}\text { Chla } \\
\left(\mu \mathrm{g} \mathrm{L}^{-1}\right)\end{array}$ & $\begin{array}{l}\text { Suspended } \\
\text { material (mg) }\end{array}$ & $\begin{array}{l}\text { Organic } \\
\text { carbon } \\
\left(\mathrm{mg} \mathrm{g}^{-1}\right)\end{array}$ \\
\hline \multicolumn{13}{|l|}{ September } \\
\hline ST1 Sep & 21.8 & 7.52 & 39.1 & 58.9 & 7.4 & 0.07 & 11.30 & 0.05 & 5.47 & 0.27 & 0.01 & 3.15 \\
\hline ST2 Sep & 22.6 & 7.71 & 39.7 & 59.5 & 10 & 0.64 & 6.19 & 0.30 & 14.88 & 0.40 & 0.04 & 3.02 \\
\hline ST3 Sep & 23.2 & 7.89 & 37.0 & 55.9 & 8.4 & 0.19 & 5.34 & 5.73 & 12.52 & 0.13 & 0.02 & 3.02 \\
\hline ST4 Sep & 23.3 & 8.06 & 37.3 & 56.2 & 9.6 & 0.00 & 18.26 & 0.12 & 6.05 & 0.27 & 0.02 & 2.90 \\
\hline ST5 Sep & 23.4 & 8.05 & 35.4 & 53.8 & 8.2 & 0.82 & 1.91 & 2.69 & 16.05 & 0.94 & 0.02 & 2.94 \\
\hline ST6 Sep & 23.5 & 8.04 & 36.4 & 55.1 & 8.8 & 0.03 & 6.07 & 0.37 & 4.29 & 0.67 & 0.01 & 3.76 \\
\hline ST7 Sep & 23.2 & 8.15 & 35.4 & 53.7 & 8.7 & 0.06 & 21.47 & 0.69 & 1.94 & 0.80 & 0.01 & 3.06 \\
\hline ST8 Sep & 23.6 & 8.08 & 36.1 & 54.6 & 9.5 & 0.13 & 18.22 & 0.44 & 11.94 & 1.47 & 0.02 & 3.14 \\
\hline ST10 Sep & 24.1 & 7.33 & 37 & 56.1 & 6.3 & 0.51 & 0.59 & 0.51 & 19.00 & 0.16 & 0.03 & 3.55 \\
\hline ST11 Sep & 24.6 & 7.72 & 36.4 & 55.4 & 5.4 & 0.84 & 9.52 & 0.05 & 15.47 & 0.27 & 0.03 & 3.51 \\
\hline ST12 Sep & 23.9 & 7.77 & 36.5 & 55.3 & 5.5 & 0.34 & 17.22 & 0.37 & 11.35 & 0.14 & 0.03 & 4.34 \\
\hline ST13 Sep & 24.3 & 7.66 & 36.4 & 55.4 & 5.9 & 0.69 & 7.02 & 0.62 & 18.41 & 0.35 & 0.03 & 2.12 \\
\hline ST14 Sep & 24.5 & 7.70 & 37.4 & 56.5 & 6 & 0.03 & 17.82 & 0.65 & 6.64 & 0.95 & 0.04 & 4.12 \\
\hline ST15 Sep & 24.3 & 7.67 & 36.7 & 55.5 & 5.6 & 0.52 & 7.83 & 0.62 & 13.70 & 0.73 & 0.06 & 2.90 \\
\hline ST16 Sep & 24.4 & 7.76 & 36.8 & 55.9 & 5.9 & 0.88 & 13.48 & 1.51 & 36.64 & 0.49 & 0.04 & 3.41 \\
\hline ST17 Sep & 24.5 & 7.79 & 34.9 & 53.4 & 6.1 & 0.64 & 3.37 & 1.08 & 16.64 & 0.67 & 0.04 & 5.08 \\
\hline ST18 Sep & 24.6 & 7.74 & 37.4 & 56.6 & 6.1 & 0.49 & 5.20 & 0.98 & 21.94 & 0.53 & 0.03 & 5.72 \\
\hline ST19 Sep & 24.4 & 7.84 & 37.7 & 57.0 & 6.2 & 0.56 & 15.88 & 0.15 & 13.11 & 0.84 & 0.03 & 7.24 \\
\hline \multicolumn{13}{|l|}{ April } \\
\hline ST1 Apr & 22.8 & 8.24 & 2.4 & 4.6 & 9.6 & 0.09 & 1.73 & 0.02 & 7.32 & 0.45 & 0.04 & \\
\hline ST2 Apr & 22.5 & 8.24 & 2.5 & 4.9 & 11 & 0.53 & 6.09 & 0.09 & 11.09 & 0.68 & 0.06 & \\
\hline ST3 Apr & 23.8 & 8.32 & 2.6 & 5.0 & 9.2 & 0.09 & 2.41 & 0.74 & 13.98 & 0.41 & 0.05 & \\
\hline ST4 Apr & 23.6 & 8.32 & 2.6 & 5.0 & 10.8 & 0.07 & 1.76 & 0.16 & 9.83 & 0.52 & 0.04 & \\
\hline ST5 Apr & 23.2 & 8.32 & 2.6 & 5.01 & 9 & 0.57 & 7.22 & 1.26 & 14.54 & 2.06 & 0.03 & \\
\hline ST6 Apr & 23.4 & 8.32 & 2.4 & 4.7 & 9.7 & 0.03 & 1.28 & 0.17 & 6.87 & 1.50 & 0.04 & \\
\hline ST7 Apr & 23.1 & 8.31 & 2.3 & 4.4 & 9.3 & 0.09 & 3.65 & 0.41 & 10.85 & 1.75 & 0.04 & \\
\hline ST8 Apr & 22.9 & 8.27 & 2.6 & 5.0 & 10.7 & 0.15 & 1.97 & 0.27 & 3.94 & 3.98 & 0.06 & \\
\hline ST9 Apr & 23.4 & 8.18 & 32.2 & 49.3 & 8.5 & 0.41 & 3.71 & 0.36 & 11.64 & 1.73 & 0.02 & \\
\hline ST10 Apr & 23.2 & 8.21 & 32.4 & 45.6 & 8.5 & 0.46 & 2.91 & 0.32 & 13.91 & 0.39 & 0.02 & \\
\hline ST11 Apr & 23.5 & 8.34 & 24.5 & 40.2 & 8.4 & 0.32 & 4.78 & 0.63 & 18.79 & 0.57 & 0.02 & \\
\hline ST12 Apr & 22.9 & 8.33 & 30 & 46.3 & 8.7 & 0.50 & 5.99 & 0.54 & 10.19 & 0.36 & 0.03 & \\
\hline ST13 Apr & 23.1 & 8.34 & 27 & 42.6 & 8.6 & 0.57 & 8.21 & 1.46 & 8.37 & 0.49 & 0.02 & \\
\hline ST14 Apr & 23.2 & 8.34 & 28.8 & 45.1 & 8.4 & 0.71 & 11.43 & 1.22 & 16.22 & 0.74 & 0.04 & \\
\hline ST15 Apr & 23.7 & 8.37 & 28.5 & 43.5 & 8.6 & 0.01 & 0.97 & 1.64 & 11.07 & 1.44 & 0.03 & \\
\hline ST16 Apr & 23.6 & 8.39 & 28.6 & 45.1 & 8.5 & 0.60 & 5.81 & 0.32 & 7.88 & 0.96 & 0.05 & \\
\hline ST17 Apr & 23.7 & 8.42 & 29 & 45.3 & 8.7 & 0.74 & 6.91 & 1.72 & 11.54 & 0.91 & 0.03 & \\
\hline ST18 Apr & 23.2 & 8.46 & 28.4 & 45.1 & 8.5 & 0.50 & 3.72 & 0.50 & 16.02 & 0.65 & 0.02 & \\
\hline ST19 Apr & 23.6 & 8.45 & 29.1 & 45.6 & 8.6 & 0.53 & 4.23 & 0.36 & 8.74 & 1.97 & 0.04 & \\
\hline ST20 Apr & 23.5 & 8.40 & 29.2 & 45.7 & 8.2 & 0.46 & 5.98 & 0.16 & 8.34 & 0.76 & 0.01 & \\
\hline
\end{tabular}

Science (Oviedo, Spain): a mix of MBT, DBT and TBT enriched in 119 Sn $(82.4 \%)$ at $0.110,0.691$ and $1.046 \mu \mathrm{g} \cdot \mathrm{g}^{-1}$, respectively.

All stock solutions ( $1000 \mu \mathrm{g} \cdot \mathrm{g}^{-1}$ as $\mathrm{Sn}$ ) were prepared by dissolving the corresponding salt in a 3:1 mixture of acetic acid/methanol and were kept in the dark at $4{ }^{\circ} \mathrm{C}$ until use. Working solutions of the organotin compounds were prepared daily before analysis by dilution of the stock solutions with $1 \% \mathrm{HCl}$ in ultrapure water.

Ichkeul Lake -Bizerte Lagoon complex is located at the Northern region of Tunisia. The Tinja River connects the Lake to the Lagoon, and several rivers feed the hydrosystem complex (Fig. 1). The complex has been exploited for fishing activities for several centuries and the lagoon for mussel farming since 1964. Bizerte Lagoon is open to the Mediterranean Sea by a channel. The area of Bizerte Lagoon is approximately $128 \mathrm{~km}^{2}$, and it is subjected to contamination from two industrial zones, one with oil refinery one with cement plant... (Ben Said et al., 2010) and agricultural lands located on the Bizerte Lagoons' edge. Covering $90 \mathrm{~km}^{2}$, Ichkeul Lake is a Biosphere reserve, a Ramsar site, and a UNESCO World Heritage Site (Stevenson, 1991; Kraïem and Ben Hamza, 2000; Ramdani et al., 2001; Ben M'Barek and Slim-Shimi,
2002). The hydrology of the complex is seasonal. During winter, Ichkeul Lake is fed by fresh water from the rivers increasing the water level. At that time, large volumes of water are spilled into Bizerte Lagoon through the Tinja River. During the summer, water levels in Ichkeul Lake are low due to high evaporation rates, coupled with lower river inflows. As a result, saline water from Bizerte Lagoon enters Ichkeul Lake through the Tinja River. This results in a saline water connection between Ichkeul Lake and the Mediterranean Sea and formerly had a seasonal salinity regime, freshwater increasing with winters' rainfall and decreasing in summer. Ichkeul Lake receives principally agricultural inputs as it is surrounded by a vast agricultural area (Stevenson and Battarbee, 1991).

A total of 40 surface sediment samples were collected by Van Veen grab from 20 stations of the Ichkeul Lake-Bizerte Lagoon complex, during two sampling periods in September 2011 and April 2012.Selected stations included mouths of rivers tributary to the lake and lagoon, stations adjacent to industrial areas, and two stations at the centers of the lake and lagoon. The locations of the sample stations are identified in Fig. 1. The sediments were placed in glass bottles and were kept frozen at $-20^{\circ} \mathrm{C}$. 


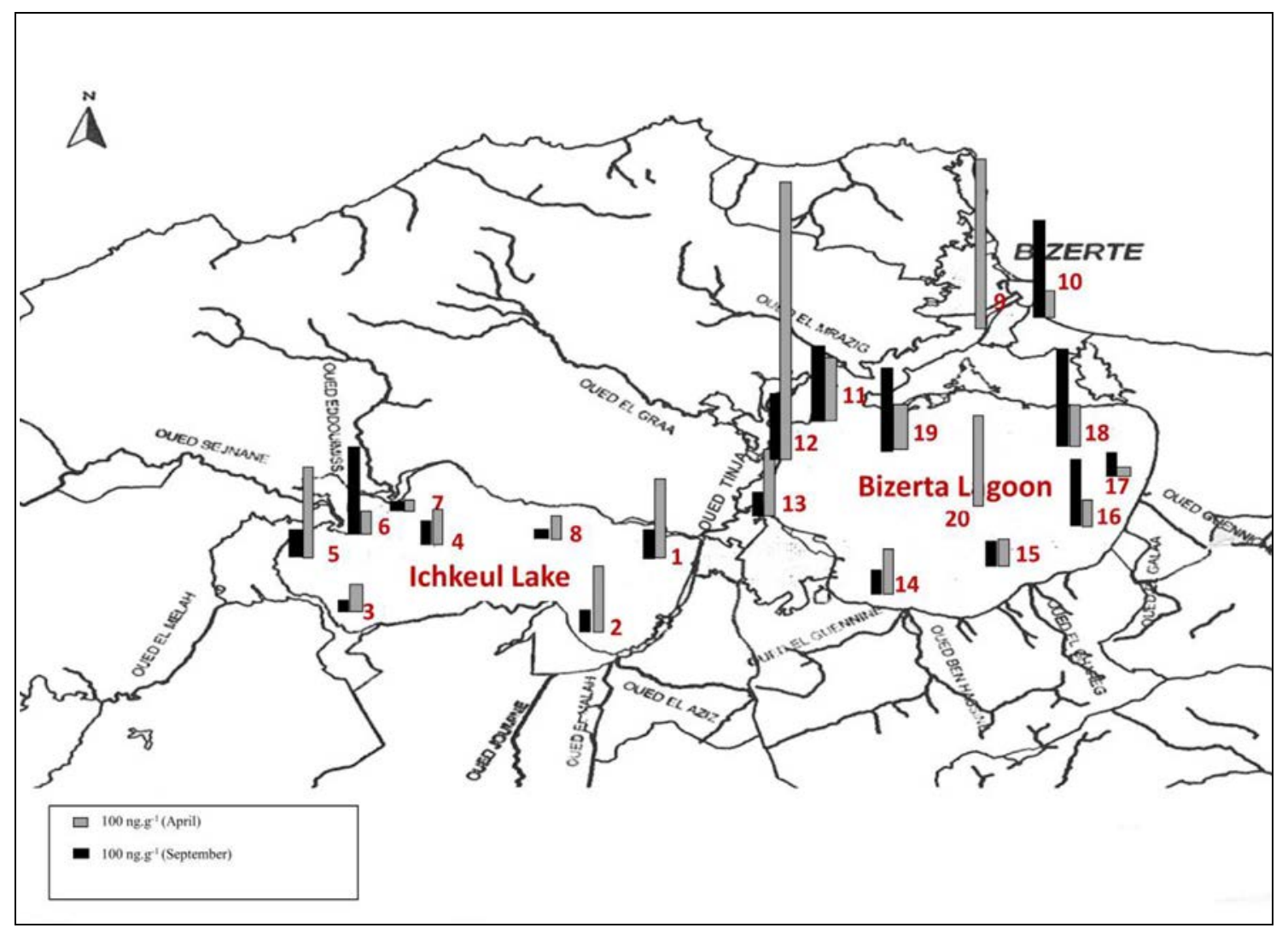

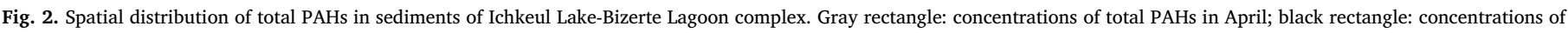
total PAHs in September.

Before analysis samples were freeze dried in a ZirBus Vaco2 lyophiliser and sieved.

Water column temperature, $\mathrm{pH}$, dissolved oxygen, salinity and conductivity were determined in the field with a handheld multiparameter system WTW Multi-197i (Table 1). Nitrite and nitrate were analyzed following the procedure of Wood et al. (1967). Ammonia was determined according to Aminot and Chaussepied (1983). Phosphate levels were determined as described in Murphy and Riley (1962). For chlorophyll $a$ (Chla), seawater samples were filtered through Whatman GF/F filters. Pigment concentrations were determined using the standard spectrophotometric method (Parsons et al., 1984), following extraction with $10 \mathrm{~mL} 90 \%$ acetone overnight at $4{ }^{\circ} \mathrm{C}$ in the dark. Suspended material was analyzed according to Baretta-Becker et al. (1994). Total organic carbon (TOC) of sediment samples was analyzed with the TOC Analyzer (SHIMADZU H544051).

The samples were analyzed according to an adapted QuEChERS method for the simultaneous analysis of OCPs, PAHs and PCBs in sediment by gas chromatography-mass spectrometry (Ben Salem et al., 2016). BuSn were analyzed according to methods validated by Moreno et al., 2006 .

The samples were analyzed according to an adapted QuEChERS method for the analysis of OCPs, PAHs and PCBs in sediment by gas chromatography-mass spectrometry. The QuEChERS method validated by Yang et al. (2010) for the analysis of pesticides in soil was adapted for the analysis of OCPs, PAHs and PCBs in sediment samples. Briefly, an aliquot of $5 \mathrm{~g}$ of sediment was weighed into a polypropylene tube
(50 mL capacity). Then, $4 \mathrm{~mL}$ ultrapure water was added, the tube was manually shaken and the internals standards (atrazine d5, PCB 30, phenanthrene-D10 and perylene-D12) were introduced. Then, $20 \mathrm{~mL}$ of extraction solvent (dichloromethane-acetone (50:50 v:v)) were added and the tube was shaken vigorously by hand for $1 \mathrm{~min}$. Then, a citrate buffer salt mixture ( $4 \mathrm{~g} \mathrm{MgSO}_{4}, 1 \mathrm{~g} \mathrm{NaCl}, 0.5 \mathrm{~g}$ disodium citrate sesquihydrate and $1 \mathrm{~g}$ of trisodium citrate dehydrate) was added and the tube was shaken vigorously manually $(5 \mathrm{~min})$. Finally, the tube was centrifuged for $3 \mathrm{~min}$ at $2500 \mathrm{rpm}$ and $10 \mathrm{~mL}$ of the supernatant were transferred into another polypropylene tube $(15 \mathrm{~mL}$ capacity) already containing $900 \mathrm{mg}$ of $\mathrm{MgSO}_{4}$ and $150 \mathrm{mg}$ primary secondary amine (PSA). The tube was shaken vigorously by hand for $30 \mathrm{~s}$ and centrifuged for $3 \mathrm{~min}$ at $2500 \mathrm{rpm}$. The extracts were then dried under a gentle argon stream using a Turbovap LV Concentration Evaporator system. The dried residue was re-dissolved with $1 \mathrm{~mL}$ acetonitrile and kept at $-20{ }^{\circ} \mathrm{C}$ until analysis.

The analyses were performed by using a gas chromatograph (Agilent 7890A) coupled to a mass spectrometer (Agilent 5975C) with an electron impact ionization source (EI). The GC-MS system was equipped with an Agilent DB5-MS UI column. The carrier gas was helium used at $1 \mathrm{~mL} \mathrm{~min}^{-1}$ flow rate. The ion source temperature and the quadrupole temperatures were kept at $230{ }^{\circ} \mathrm{C}$ and $150{ }^{\circ} \mathrm{C}$, respectively. A sample volume of $1 \mu \mathrm{L}$ of the extracts was injected in pulsed splitless mode at an inlet temperature of $280{ }^{\circ} \mathrm{C}$. The column temperature was programmed as follows: the initial oven temperature was set at $80^{\circ} \mathrm{C}$ for $1 \mathrm{~min}$, increased to $160^{\circ} \mathrm{C}$ at $10{ }^{\circ} \mathrm{C} / \mathrm{min}$ (hold $5 \mathrm{~min}$ ), then ramped 
a

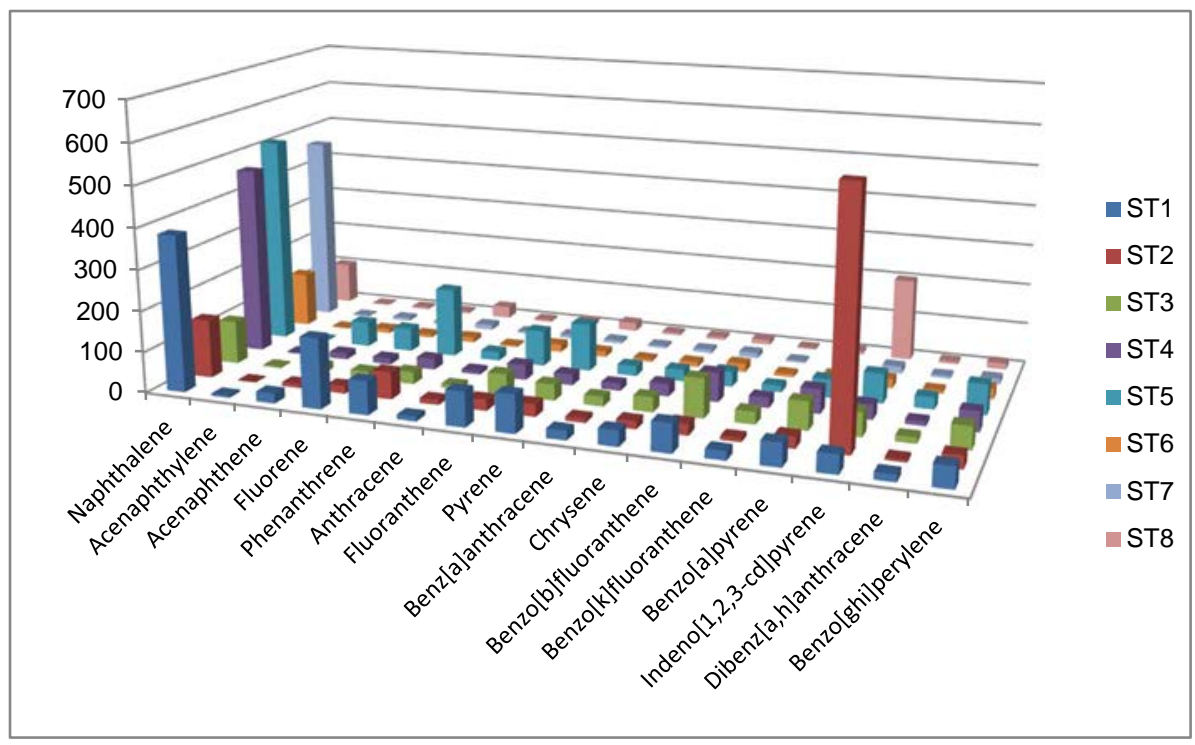

b

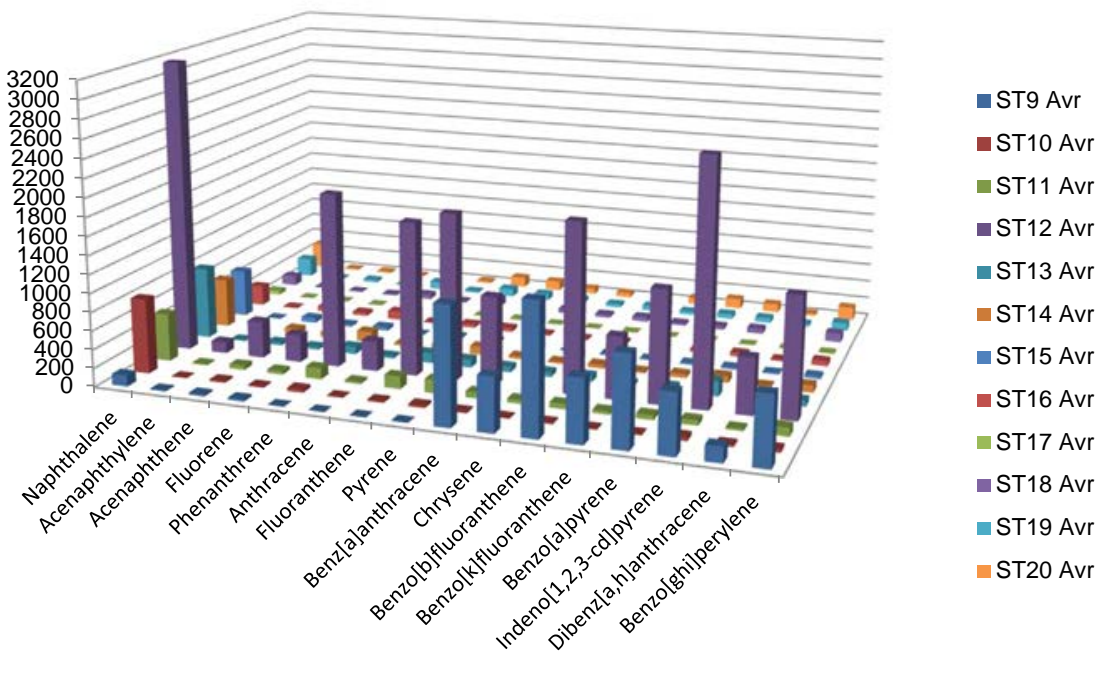

Fig. 3. a. Concentrations (ng.g ${ }^{-1}$ dry wt) of PAHs in sediment of different sites from Ichkeul Lake in April. b. Concentrations (ng. $\mathrm{g}^{-1}$ dry wt) of PAHs in sediment of different sites from Bizerte lagoon in April.

Table 2

Threshold effects level (TEL) (ng.g ${ }^{-1}$ dry wt) of OCPs from NOAA screening quick references table.

\begin{tabular}{lll}
\hline Compounds & Marine sediment & Freshwater sediment \\
\hline Lindane & 0.32 & 0.94 \\
Chlordane & 2.26 & 4.5 \\
p,p DDD & 1.22 & 3.54 \\
p,p DDE & 2.07 & 1.42 \\
p,p DDT & 1.19 & - \\
DDT total & 3.89 & 6.98 \\
Dieldrin & 0.715 & 2.85 \\
Endrin & - & 2.67 \\
Heptachlor epoxide & - & 0.6 \\
\hline
\end{tabular}




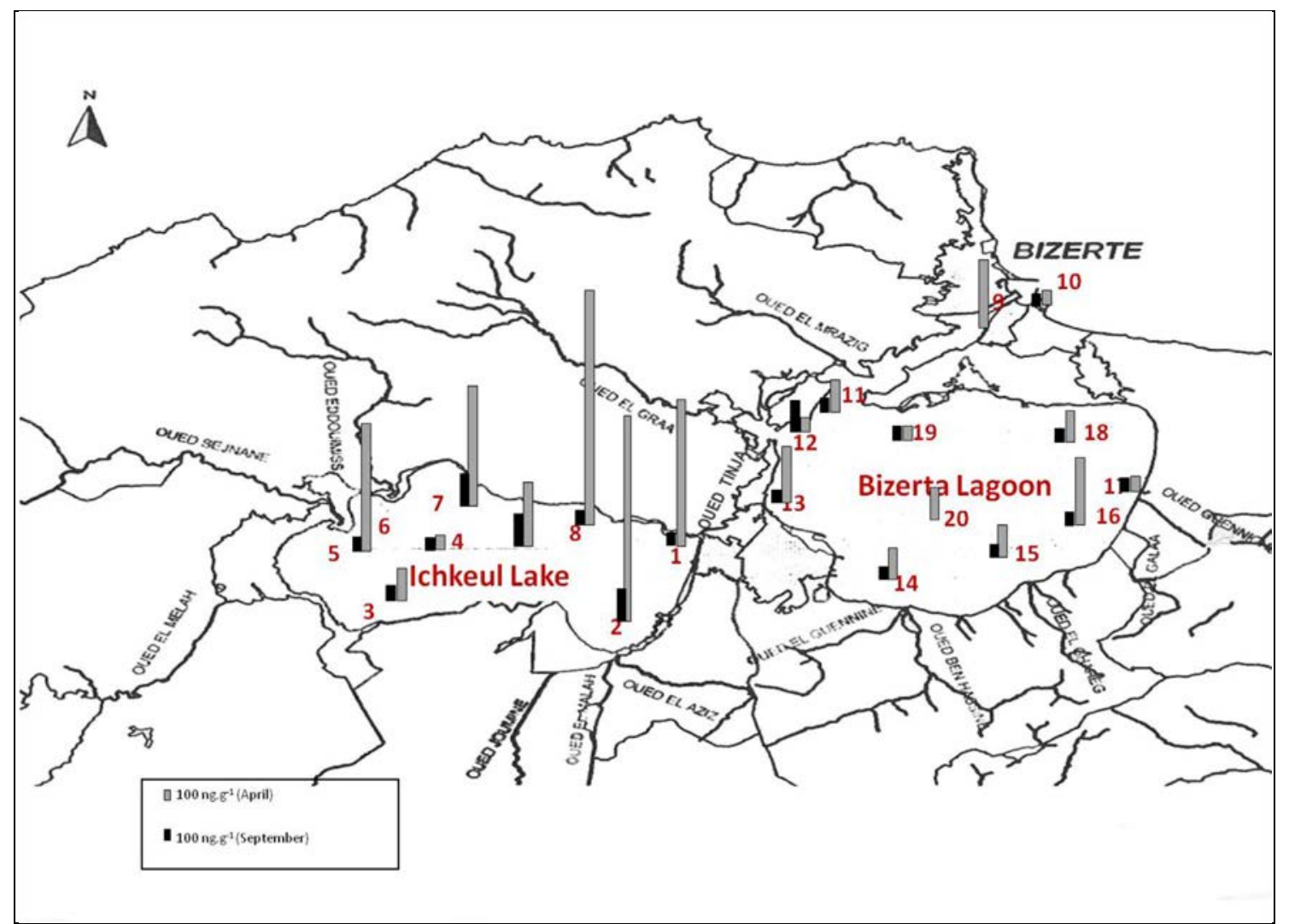

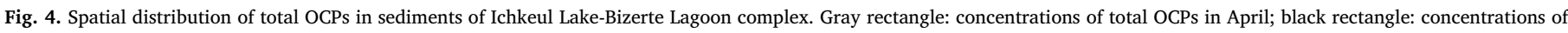
total OCPs in September.

at $3{ }^{\circ} \mathrm{C} / \mathrm{min}$ to $300{ }^{\circ} \mathrm{C}$ (hold $2 \mathrm{~min}$ ). The MS interface temperature was maintained at $300{ }^{\circ} \mathrm{C}$. The quantification was carried out in the selected ion monitoring mode (SIM) selecting two characteristics fragments ions for each compound. Two replicates were performed for each sample with two injections. An internal standard correction was used for the quantification of the analytes.

The accuracy of the method was evaluated by the recoveries obtained for the certified reference sediment. The obtained data show acceptable recoveries ranging from $60 \%$ to $103 \%$ for PAHs, from 76 to $131 \%$ for PCBs and from 81 to $137 \%$ for pesticides.

Data were detected and their concentrations were analyzed using mean \pm SD.

The physical and chemical parameters observed in the sampling stations are summarized in Table 1.Water temperature at all sampled stations exhibited comparable temporal fluctuation from 21.8 to $24.6{ }^{\circ} \mathrm{C}$ in September and from 22.5 to $23.7^{\circ} \mathrm{C}$ in April (Table 1). In dry season, salinity varied from 34.9 to 37.7 PSU in Bizerte Lagoon and from 34.4 to 39.7 PSU in Ichkeul Lake. In rainy season, salinity varied from 31.2 to 34.4 PSU in Bizerte Lagoon and from 2.3 to 2.6 PSU in Ichkeul Lake. The reduction in salinity between seasons at Ichkeul Lake from 35 to $2.5 \mathrm{PSU}$ is due to the contribution of continental water from dams and rivers. In Bizerte Lagoon, the channel and marine stations 9, 10 are submitted to the marine influence with higher salinities.

All PAH target compounds were detectable in sediment samples collected from the complex Ichkeul Lake-Bizerte Lagoon. Total PAHs ranged from 122 to $19,600 \mathrm{ng} \cdot \mathrm{g}^{-1}$ dry wt with mean of $1576 \mathrm{ng} \cdot \mathrm{g}^{-1}$ dry wt. Bizerte Lagoon was much more contaminated with PAHs than
Ichkeul Lake for two campaigns September and April. In September 2011, stations 11, 18 and 19 were the most contaminated at Bizerte Lagoon. Stations 9 and 12 were the most affected in April (Fig. 2). The station 11 located in the way of boats between Mediterranean Sea and Menzel Bourguiba harbor, and stations 18, near the industrial area, were contaminated by PAHs in April 2011, and previously reported by Ben Said et al. (2010). It is not surprising to found high PAHs levels in the stations 9 and 12 since they are located at the channel of Bizerte Lagoon, which is probably impacted by maritime traffic of Menzel Bourguiba Harbor. The results are comparable to those reported previously (Mzoughi et al., 2005; Ben Said et al., 2010). Station 17 at Bizerte Lagoon was the less contaminated in April than in September. This station is always subjected to water flow with permanent water renewal eliminating all type of contaminant (Harzallah, 2003).

For the Ichkeul Lake, stations 1, 5, and 6 were most PAHs contaminated in September 2011. In April, stations 1, 2 and 5 were most affected by PAHs. Whatever season, the least PAHs contamination in Ichkeul Lake was at station 7 . These results indicate that contamination by PAHs in the lagoon and lake mainly due to accumulation of PAH in sediment from the maritime traffic. Seasonal variation showed that contamination by PAHs was stronger in rainy season (April) than in dry season (September) for the two ecosystems studied. These results were consistent with those obtained by Mzoughi et al. (2005, 2002). Individual PAHs with the highest concentrations are naphthalene, indeno $[1,2,3 c d]$ pyrene, phenanthrene, benzo[b]fluoranthene, and fluoranthene, in descending order (Fig. 3a and b). Comparison with threshold published by the National Oceanic and Atmospheric 
a.

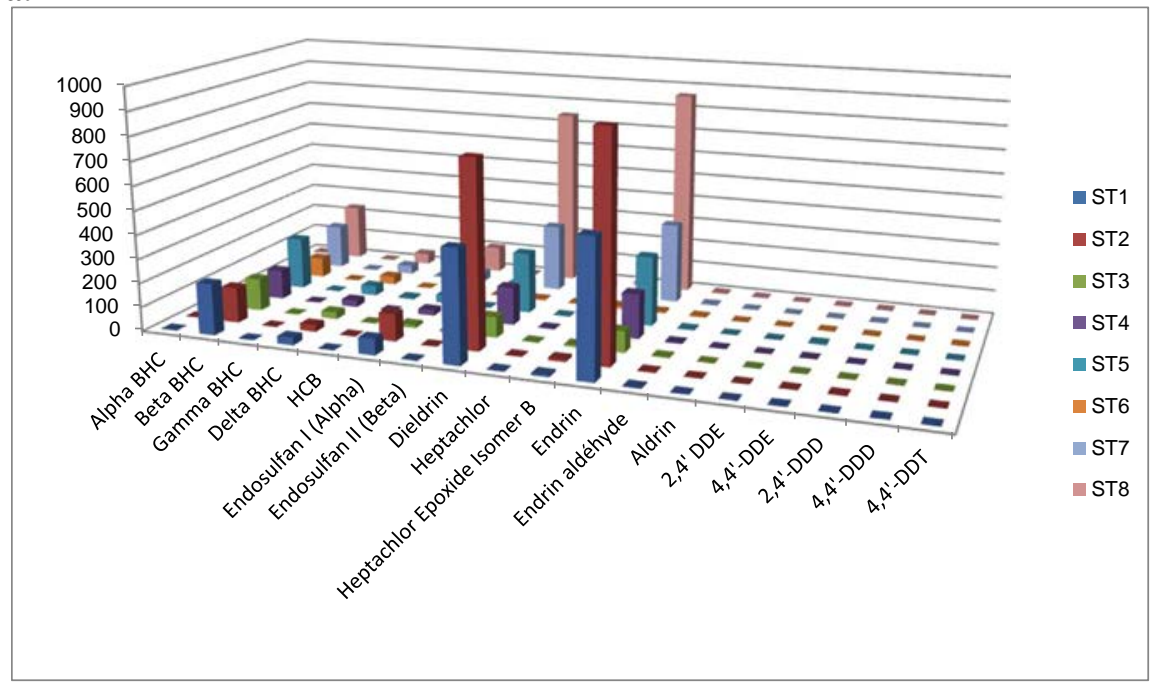

b.

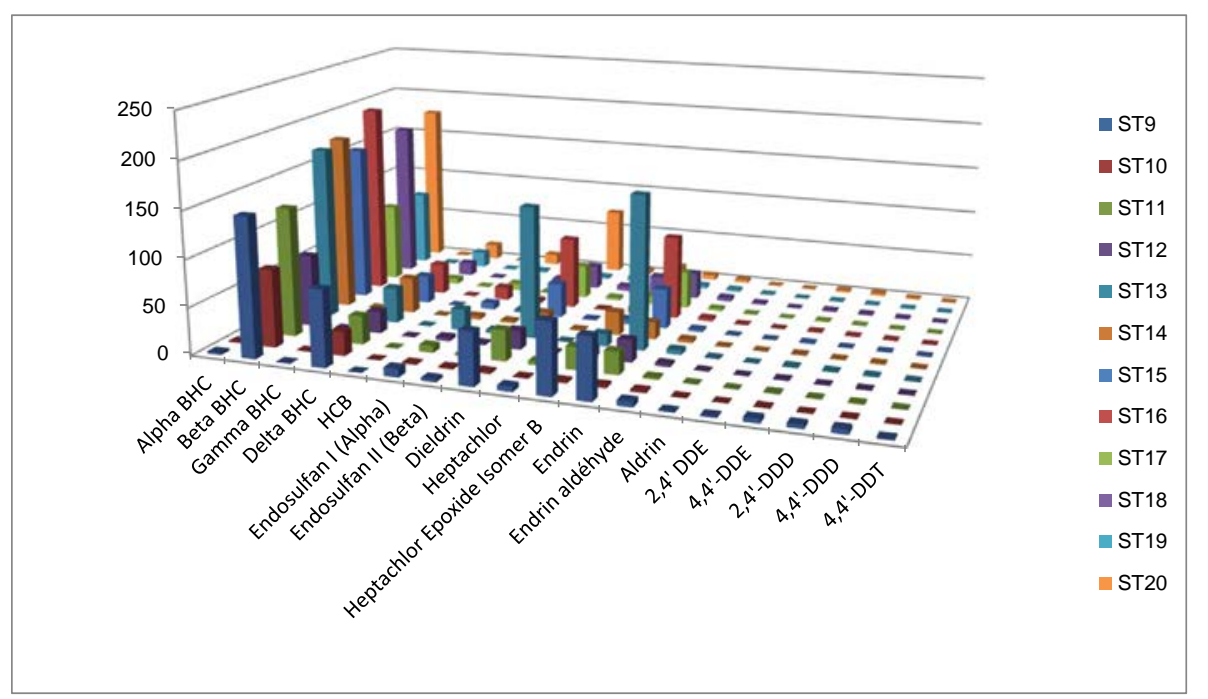

Fig. 5. a. Concentrations (ng.g ${ }^{-1}$ dry wt) of OCPs in sediment of different sites from Lake Ichkeul in April. b. Concentrations (ng.g ${ }^{-1}$ dry wt) of OCPs in sediment of different sites from Bizerte lagoon in April.
Administration (NOAA): the Threshold Effects Level (TEL) and Probable Effects Level (PEL), showed that the PAHs contents in stations 6, 9, 10, 12, 18 exceeded the TEL (Table 2), station 12 exceeding the PEL.

Pesticides were detectable in sediment from all prospected stations of the complex. Total OCPs ranged from 34 to $2021 \mathrm{ng} \cdot \mathrm{g}^{-1}$ dry wt with mean of $1576 \mathrm{ng} \cdot \mathrm{g}^{-1}$ dry wt. Lake Ichkeul was more contaminated by OCPs than Bizerte lagoon regardless of the season. Stations 2, 8 and 1 were the most contaminated (Fig. 4). The maximum concentration of endrin was recorded at station 2 and the minimal at station 6 (Fig. 5a). Regarding Dieldrin, the highest concentrations were observed at stations 8, 2 and 1(Fig. 5). The lowest concentration was detected at the station 6. Lindane $(\mathrm{HCH})$ was detected in all stations with comparable concentrations. The maximum dose was detected in station 8 and the minimum at station 6 (Fig. 5a). Endosulfan has been detected in the sediments of different stations with maximum at stations 8 and 2 (Fig. 5a). Heptachlor, Aldrin, Hexachlorobenzene (HCB), dichlorodiphenyltrichloroethane (DDTs), chlordane and nonachlor were detected in the different stations, but at very low concentrations (Fig. 5a and b). A maximum total concentration of up to $2021 \mathrm{ng} \cdot \mathrm{g}^{-1}$ dry wt OCPs was detected in the sediments from stations 8 (Fig. 4). Interestingly station 2 is located near agricultural areas (4102 ha) of the office of public lands. Station 8 was the only station chosen because it is not located in the mouth of a river in order to estimate the effect of direct runoff from agricultural areas. According to the results, it is likely that direct runoff had a greater effect in the transport of pesticides that rivers flow. This observation may be explained by a dilution effect in rivers. These concentrations were in the same range of those detected by Ben Ameur et al. (2013) in the tissues of fishes Mugilcephalus and Dicentrarchus labrax in Bizerte Lagoon from 1.25 to $227 \mathrm{ng} \cdot \mathrm{g}^{-1}$ dry wt. Lindane (HCH), Dieldrin and Endrin are the most represented in the sediments of Ichkeul Lake. The OCPs were detected at low levels in all stations of Bizerte Lagoon. The OCPs contents exceeded the threshold of the standards published by NOAA (Table 2) in almost all stations in the lake and lagoon. The effect of the OCPs detected on bacteria and free-living marine nematodes in station 6, 8, 13, 17 was investigated in Ben Salem et al. (2016). 


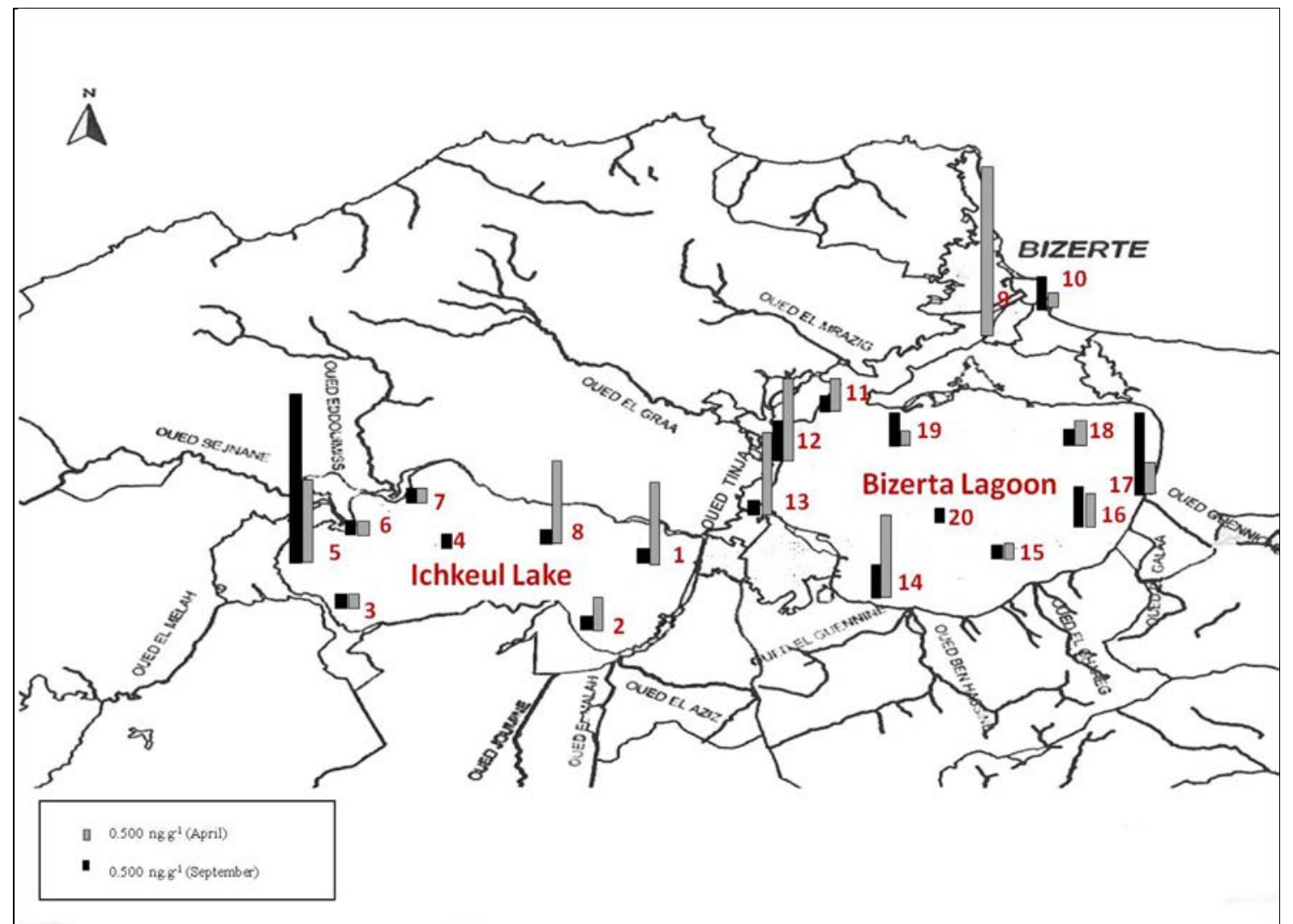

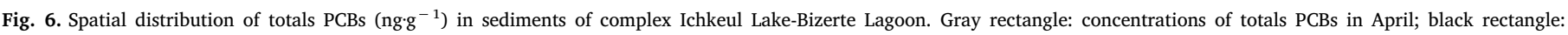
concentrations of totals PCBs in September.

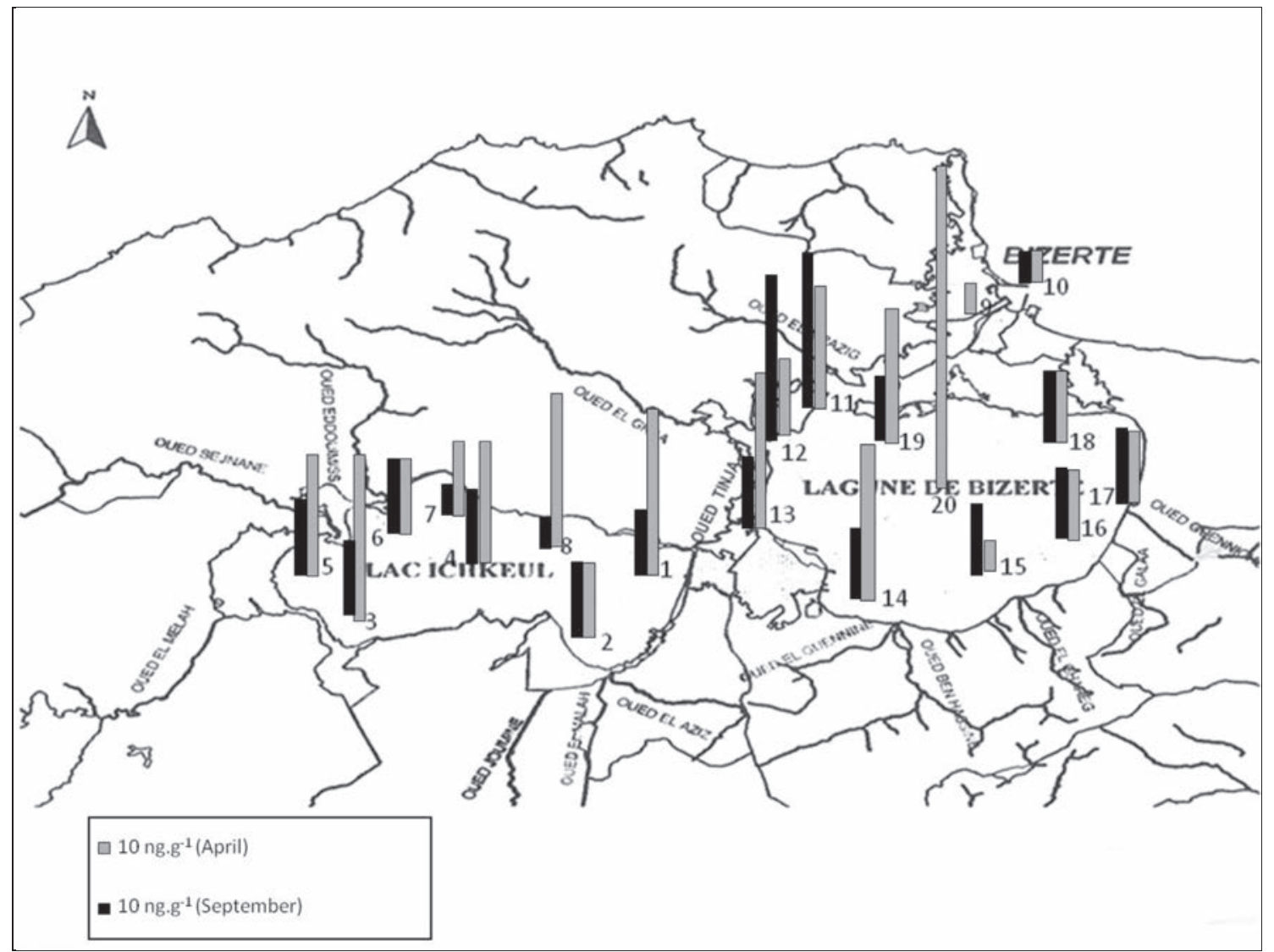

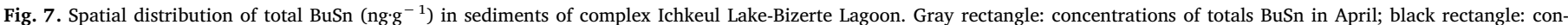
centrations of totals BuSn in September. 
Concentrations of total PCBs detected in the sediment of Ichkeul Lake-Bizerte Lagoon complex were ranged between 0.004 and $10.653 \mathrm{ng} \cdot \mathrm{g}^{-1}$ dry wt. The levels were relatively low. This result is comparable to the range of concentrations of PCBs detected in sediment from Monastir Bay in Tunisia (1.1 and $9.3 \mathrm{ng} \cdot \mathrm{g}^{-1}$ ) (Nouira et al., 2013). However, the contents detected in the tissues of fish Mugilcephalus and Dicentrarchus labrax from Bizerte Lagoon were higher in the range of 1.43-156 ng.g ${ }^{-1}$ wt (Ben Ameur et al., 2013), probably due to biomagnification. There was not a clear seasonal and spatial variation between the Ichkeul Lake and the Bizerte Lagoon (Fig. 6) as reported previously by Nouira et al. (2013), except for station 9 at Bizerte Lagoon which was more contaminated than the other stations in April, and for station 5 at Ichkeul Lake in September (Fig. 6). The complex Ichkeul Lake-Bizerte Lagoon was not affected by PCBs. PCBs contents exceeding neither the threshold set by NOAA nor the Interim sediment quality guidelines (ISQGs) for total PCBs, which is determined at $21.5 \mu \mathrm{g} \cdot \mathrm{kg}^{-1}$ dry wt for marine sediment and at $34.1 \mu \mathrm{g} \cdot \mathrm{kg}^{-1} \mathrm{dry} \mathrm{wt}$ for freshwater sediment. The probable effect levels (PELs) for total PCBs being $189 \mu \mathrm{g} \cdot \mathrm{kg}^{-1}$ for marine sediment and $277 \mu \mathrm{g} \cdot \mathrm{kg}^{-1}$ for freshwater sediment.

Concentrations of total BuSn detected in the sediment of Ichkeul Lake-Bizerte Lagoon complex were ranged between 67.5 and $526.1 \mathrm{ng} \cdot \mathrm{g}^{-1}$ dry wt. Generally there is no difference between two stations (lake and lagoon) and seasons (Fig. 7), except the station 20 from the lagoon indicates a high level of BuSn (526.1 ng.g ${ }^{-1}$ dry wt). The lagoon stations close to the ship repair industry are the most contaminated. As regards the Lake, station 1 where load the fishing boats is the most contaminated and the stations submitted to maritime traffic are also contaminated. Concentrations of BuSn detected in the sediments of the lake/lagoon complex were relatively low compared to norms. The spatial distribution of BuSn in the sediment of complex shows that stations subjected to the action of maritime traffic are most contaminated but the contents are substandard.

The Ichkeul Lake was found with high levels of OCPs contents. The OCPs input is probably coming from the agricultural areas located at the edge of this aquatic ecosystem. Bizerte Lagoon was found with high levels of PAHs contents, which are probably coming from the maritime traffic. The PCBs and BuSn content levels were found low indicating that there was not a real contamination by these compounds. The hydrological characteristics of the complex Ichkeul Lake-Bizerte Lagoon, such as seasonal variation of flow rates, may influence the spatial and temporal distribution of persistent organic pollutants in sediments. It is thus important to survey the impact of human activities on the Ichkeul Lake-Bizerte Lagoon hydrologic complex in order to protect this area with high ecosystemic value.

\section{Acknowledgements}

The authors would like to thank Mme Nabiha M'barek (National Agency of Environment Protection Tunisia) and Mr. Taher Kaabi (Commissariat Regional Commission for Agricultural Development of Bizerte) for their logistic contribution. We acknowledge the Regional Platform for Environmental Microbiology PREMICE supported by the Aquitaine Regional Government Council (France) and the urban community of Pau-Pyrénées (France).

\section{Appendix A. Supplementary data}

Supplementary data to this article can be found online at http://dx. doi.org/10.1016/j.marpolbul.2017.09.024.

\section{References}

Aminot, A., Chaussepied, M., 1983. Manuel des analyses chimiques en milieu marin. Centre national pour l'exploitation des océans, Brest (ISBN: 2.902721.10.2). Baretta-Becker, J.G., Riemann, B., Baretta, J.W., Rasmussen, E.K., 1994. Testing the microbial loop concept by comparing mesocosm data with results from a dynamical simulation model. Mar. Ecol. Prog. Ser. 106, 187-198.

Ben Ameur, W., Trabelsi, S., El Megdiche, Y., Ben Hassine, S., Barhoumi, B., Hammami, B., Eljarrat, E., Barceló, D., Driss, M.R., 2013. Concentration of polychlorinated biphenyls and organochlorine pesticides in mullet (Mugil cephalus) and sea bass (Dicentrarchus labrax) from Bizerte Lagoon (Northern Tunisia). Chemosphere 90, 2372-2380.

Ben Hassine, S., Ben Ameur, W., Gandoura, N., Driss, M.R., 2012. Determination of chlorinated pesticides, polychlorinated biphenyls, and polybrominated diphenyl ethers in human milk from Bizerte (Tunisia) in 2010. Chemosphere 89, 369-377.

Ben M'Barek, N., Slim-Shimi, N., 2002. Evolution des parmètres physico-chimiques des eaux du lac Ichkeul après la réalisation des aménagements hydrauliques (Tunisie). In: Proceedings of International Symposium and Workshop on Environmental Pollution Control and Waste Management 7-10 January 2002, Tunis (EPCOWM'2002), pp. 20-27 (in French).

Ben Said, O., Goñi-Urriza, M., El Bour, M., Aissa, P., Duran, R., 2010. Bacterial community structure of sediments of the Bizerte Lagoon (Tunisia), a Southern Mediterranean Coastal Anthropized Lagoon. Microb. Ecol. 59, 445-456.

Ben Salem, F., Ben Said, O., Aissa, P., Mahmoudi, E., Monperrus, M., Grunberger, O., Duran, R., 2016. Pesticides in Ichkeul Lake-Bizerte Lagoon Watershed in Tunisia: use, occurrence, and effects on bacteria and free-living marine nematodes. Environ. Sci. Pollut. Res. 23, 36-48.

Birch, G.F., Davey, S., 1995. Accumulation of metallic contaminants in surficial sediments on a high energy continental shelf (Sydney, Australia). Sci. Total Environ. 170, 81-93.

Chang, K.F., Fang, G.C., Chen, J.C., Wu, Y.S., 2006. Atmospheric polycyclic aromatic hydrocarbons (PAHs) in Asia: a review from 1999 to 2004. Environ. Pollut. 142, 388-396.

Deycard, V.N., Schäfer, J., Blanc, G., Coynel, A., Petit, J.C.J., Lanceleur, L., Dutruch, L., Bossy, C., Ventura, A., 2014. Contributions and potential impacts of seven priority substances (As, Cd, Cu, Cr, Ni, Pb, and $\mathrm{Zn}$ ) to a major European Estuary (Gironde Estuary, France) from urban wastewater. Mar. Chem. 167, 123-134.

Ennaceur, S., Gandoura, N., Driss, M.R., 2008. Distribution of polychlorinated biphenyls and organochlorine pesticides in human breast milk from various locations in Tunisia: levels of contamination, influencing factors, and infant risk assessment. Environ. Res. 108, 86-93.

Harzallah, A., 2003. Transport des polluants dans la lagune de Bizerte simulé par un modèle de circulation de l'eau. 30. Institut National des Sciences et Technologies de laMer de Salammbô, pp. 115-133.

Kraïem, M.M., Ben Hamza, C., 2000. Sites description, water chemistry and vegetation transect of Tunisian lakes. Fish populations study of the nine CASSARINA lakes. In: London, CASSARINA Final Reports. Unpubl Report of INSTM, Salambo, pp. 74.

Kukucka, P., Audy, O., Kohoutek, J., Holt, E., Kalábová, T., Holoubek, I., Klánová, J., 2015. Source identification, spatio-temporal distribution and ecological risk of persistent organic pollutants in sediments from the upper Danube catchment. Chemosphere 138, 777-783.

Moreno, M.J., Pacheco-Arjona, J., Rodriguez-Gonzalez, P., Preud'Homme, H., Amouroux, D., Donard, O.F.X., 2006. Simultaneous determination of monomethylmercury, monobutyltin, dibutyltin and tributyltin in environmental samples by multi-elementalspecies-specific isotope dilution analysis using electron ionisation GC-MS. J. Mass Spectrom. 41, 1491-1497.

Murphy, J., Riley, J.P., 1962. A modified single solution method for the determination of phosphate in natural waters. Anal. Chim. Acta 27, 31-36.

Mzoughi, N., Hellal, F., Dachraoui, M., Villeneuve, J.P., Cattini, C., de Mora, S.J., El Abed, A., 2002. Méthodologie de l'extraction des hydrocarbures aromatiques polycycliques. Application à des sédiments de la lagune de Bizerte (Tunisie). Compt. Rendus Geosci. 334, 893-901.

Mzoughi, N., Lespes, G., Bravo, M., Dachraoui, M., Potin-Gautier, M., 2005. Organotin speciation in Bizerte lagoon (Tunisia). Sci. Total Environ. 349, 211-222.

Nouira, T., Risso, C., Chouba, L., Budzinski, H., Boussetta, H., 2013. Polychlorinated biphenyls (PCBs) and polybrominated diphenyl ethers (PBDEs) in surface sediments from Monastir Bay (Tunisia, Central Mediterranean): occurrence, distribution and seasonal variations. Chemosphere 93, 487-493.

Opel, O., Palm, W.U., Steffen, D., Ruck, W.K.L., 2011. Inside-sediment partitioning of $\mathrm{PAH}, \mathrm{PCB}$ and organochlorine compounds and inferences on sampling and normalization methods. Environ. Pollut. 159, 924-931.

Parsons, T.R., Takahashi, M., Hargrave, B., 1984. Biological Oceanographic Processes, third ed. Pergamon Press, Oxford, pp. 330

Pozo, K., Urrutia, R., Mariottini, M., Rudolph, A., Banguera, J., Pozo, K., Parra, O., Focardi, S., 2014. Levels of persistent organic pollutants (POPs) in sediments from Lenga estuary, central Chile. Mar. Pollut. Bull. 79, 338-341.

Ramdani, M., Flower, R.J., Elkhiati, N., Kraïem, M.M., Fathi, A.A., Birks, H.H., Patrick, S.T., 2001. North African wetland lakes: characterization of nine sites included in the CASSARINA project. Aquat. Ecol. 35, 281-302.

Sharma, B.M., Bharat, G.K., Tayal, S., Nizzetto, L., Čupr, P., Larssen, T., 2014 Environment and human exposure to persistent organic pollutants (POPs) in India: a systematic review of recent and historical data. Environ. Int. 66, 48-64.

Shu, Y.Y., Lao, R.C., Chiu, C.H., Turle, R., 2000. Analysis of polycyclic aromatic hydrocarbons in sediment reference materials by microwave-assisted extraction. Chemosphere 41, 1709-1716.

Stevenson, A.C., 1991. Palaeoecological and documentary records of recent environmental change in Garaet el Ichkeul: a seasonally saline lake in NW Tunisia. Biol. Conserv. 58, 275-295.

Stevenson, A.C., Battarbee, R.W., 1991. Palaeoecological and documentary records of recent environmental change in Garaet el Ichkeul: a seasonally saline lake in NW Tunisia. Biol. Conserv. 58, 275-329. 
Tolosa, I., de Mora, S.J., Fowler, S.W., Villeneuve, J.-P., Bartocci, J., Cattini, C., 2005. Aliphatic and aromatic hydrocarbons in marine biota and coastal sediments from the Gulf and the Gulf of Oman. Mar. Pollut. Bull. 50, 1619-1633.

Trabelsi, S., Driss, M.R., 2005. Polycyclic aromatic hydrocarbons in superficial coastal sediments from Bizerte Lagoon, Tunisia. Mar. Pollut. Bull. 50, 344-348.

Vane, C.H., Harrison, I., Kim, A.W., 2007. Assessment of polyaromatic hydrocarbons (PAHs) and polychlorinated biphenyls (PCBs) in surface sediments of the Inner Clyde Estuary, UK. Mar. Pollut. Bull. 54, 1287-1306.

Wen, J., Jirka, G.H., Raggio, G., 1994. Linked sediment/contaminant transport model for rivers with application to the Buffalo River, New York. J. Great Lakes Res. 20, 671-682.
Wenzel, W.W., Reinhard, U., Sommer, P., Sacco, P., 2003. Chelate-assisted phytoextraction using canola (Brassica napus L.) in outdoors pot and lysimeter experiments. Plant Soil. 249, 83-96.

Wood, E.D., Armstrong, F.A.J., Richards, F.A., 1967. Determination of nitrate in sea water by cadmium-copper reduction to nitrite. J. Mar. Biol. Assoc. U. K. 47, 23-31.

Yang, X.B., Ying, G.G., Kookana, R.S., 2010. Rapid multiresidue determination for currently used pesticides in agricultural drainage waters and soils using gas chromatography-mass spectrometry. J. Environ. Sci. Health B 45, 152-161.

Yang, X., Wang, F., Meng, L., Zhang, W., Fan, L., Geissen, V., Ritsema, C.J., 2014. Farmer and retailer knowledge and awareness of the risks from pesticide use: a case study in the Wei River catchment, China. Sci. Total Environ. 497-498, 172-179. 